\section{Formation of Ethylnitrolic Acid by the Reaction of Sorbic Acid with Sodium Nitrite}

\author{
Mitsuo NAMIKI and Tsuneo KADA* \\ Department of Food Science \& Technology, Faculty \\ of Agriculture, Nagoya University, Nagoya \\ * National Institute of Genetics, \\ Mishima, Shizuoka-ken
}

Received March 3, 1975

As well known, sorbic acid and sodium nitrite are corrently utilized as food additives; the former as an antimicrobial in various foods and the latter as a fixative of characteristic color of meat products. It is therefore, probable that these additives are present together in some foods especially in the case of fish meat products such as fish sausage.

Recently, one of the authors found that a potential activity in the "rec-assay" test was developed when sorbic acid solution was heated with sodium nitrite. ${ }^{1)}$ In order to elucidate the entity of the developed effect, the isolation and identification of the reaction products of sorbic acid with sodium nitrite was undertaken, and this report is concerned with the formation of ethylnitrolic acid as a main product of the activity.

All the materials and other reagents used were of guaranteed grade. A solution of sodium nitrite was added to a partially suspended solution of sorbic acid, each $0.5 \mathrm{M}$ in distilled water, at room temperature and heated in a water bath at $90^{\circ} \mathrm{C}$ for $1 \mathrm{hr}$. The mixture colored yellow instantaneously, it turned red and finally became dark red with heating, where $\mathrm{pH}$ of the mixture changed from 4.3 at the beginning to 6.0 in the final stage. The reaction mixture was extracted two times with dichloromethane and then three times with ether, and each of the extracts was concentrated in vacuo to give a dark red oily product. They were subjected to thin-layer chromatography (tlc) of the silica gel containing a fluorescent indicator (Wako gel B5-FM) with chloroformmethanol system $(95: 5, \mathrm{v} / \mathrm{v})$. The dichloromethane extract exhibited three main spots and the ether extract showed several spots, which were detectable by characteristic fluorescent colors under UV illumination. In the former tlc, the largest spot observed near the original point and colored red with UV illumination was known to be mostly unchanged sorbic acid by comparing with authentic sample. The same spot was also observed in the latter tlc, but in that a new spot showing a characteristic dark violet fluorescence with UV light was observed near $R f 0.4$.

Then, the bands of preparative tlc were scraped off corresponding to each of these spots and the extracts of them were employed for the growth inhibitory activity test. This was done by using $E$. coli $\mathrm{B}-110$ as a test microorganism and incubated with shaking at $37^{\circ} \mathrm{C}$ in the synthetic medium $\left(\mathrm{KH}_{2} \mathrm{PO}_{4}, 13.6 \mathrm{~g}\right.$; $\mathrm{NaCl}, 0.5 \mathrm{~g} ; \mathrm{MgSO}_{4} \cdot 7 \mathrm{H}_{2} \mathrm{O}, 0.2 \mathrm{~g} ;\left(\mathrm{NH}_{4}\right)_{2} \mathrm{SO}_{4}$, $2.0 \mathrm{~g} ; \mathrm{FeSO}_{4} \cdot 7 \mathrm{H}_{2} \mathrm{O}, 0.0005 \mathrm{~g}$; glucose $4.0 \mathrm{~g}$ in 1 liter distilled water, $\mathrm{pH} 7.0$ ) with or without the addition of testing sample, the inoculam size was about $5 \times 10^{6}$ cells $/ \mathrm{ml}$. The activity was compared by turbidimetry in a Fuji photoelectrometer with the effective concentration or degree of dilution to inhibit completely the growth of the cells after incubation for $24 \mathrm{hr}$. The results obtained indicate that a marked activity was present especially on the band which showed a characteristic dark blue fluorescence with UV light.

The ether extract was chromatographed on a silica gel columun with chloroform-methanol (99:1,v/v) and the eluated fractions which gave a single spot of the active product were collected. The effluent was concentrated to give a crystalline product which gave a pale yellow needles by recrystallization from dichloromethane- $n$-hexane, $\operatorname{mp} 83.5 \sim 84^{\circ} \mathrm{C}$. UV $\lambda_{\max }$ in $\mathrm{nm}, 240$ (in distilled water), 326 (at pH 12) and 224 (in $n$-hexane). IR $\nu_{\max }^{\mathrm{KBr}} 3300$ (b), 1562(s), 1384(s), 1344(s), 1179, 1050(s), 850(s), $740 \mathrm{~cm}^{-1}$. NMR $\left(\delta\right.$, in $\left.\mathrm{CDCl}_{3}\right) 2.5(3 \mathrm{H}, \mathrm{s})$ and $9.9\left(1 \mathrm{H}\right.$, broad and disappeared by $\mathrm{D}_{2} \mathrm{O}$ addition). Anal. Found: C, 23.09; H, 3.78; N, 
27.52; Calcd. for $\mathrm{C}_{2} \mathrm{H}_{4} \mathrm{~N}_{2} \mathrm{O}_{3}: \mathrm{C}, 23.07 ; \mathrm{H}, 3.88$; N, 26.92\%.

Among the known compounds presented by the calculated molecular formula, ethylnitrolic acid and methazonic acid are most probable from their mp, but the UV and IR spectral data of the isolated compound are found to be in good agreement with those have been presented on ethylnitrolic acid ${ }^{2,3} \quad \mathrm{CH}_{3} \cdot \mathrm{C}$ $(=\mathrm{NOH}) \mathrm{NO}_{2}$. The NMR data support its structure and the presence of oxim group was also suggested by the development of a characteristic green color on the tlc spot by the spray of $\mathrm{CuCl}_{2}$ solution. The above presumption was confirmed by the complete agreement between the above data and those obtained on the authentic ethylnitrolic acid which was synthesized from nitroethane and sodium nitrite by a method similar to that described by $\mathrm{V}$. Meyer. ${ }^{3)}$

Previous investigations on ethylnitrolic acid have dealt almost exclusively with its chemical properties, and little attention has been paid to its biological effect.

In the present microbial assay, the isolated compound, ethylnitrolic acid, was revealed to have a strong activity in comparison with the original materials; ethylnitrolic acid, sorbic acid and sodium nitrite were effective at the concentrations of $0.025 \sim 0.05 \mathrm{mg}, 2 \sim 4 \mathrm{mg}$ and $1.5 \sim 3 \mathrm{mg}$ per $\mathrm{ml}$, respectively.

A noteworthy fact is that ethylnitrolic acid showed a marked potency in the "rec-assay,"4 using wild and recombinationless strains of Bacillus subtillis, which means it causes damages on bacterial DNA. Thus, it was demonstrated that the reaction of sorbic acid with sodium nitrite resulted in formation of ethylnitrolic acid as a strong antibacterial agent, though there remained some other active fractions in the reaction products than ethylnitrolic acid.

It was also to be noted that the results were obtained under special in vitro experimental conditions especially in acid solution, so it does not necessarily mean that ethylnitrolic acid is actually formed in foodstuffs containing sorbic acid and sodium nitrite together. However, it seems very important to check this problem further. Details of the reaction conditions in the formation of ethylnitrolic acid and other products as well as their biological activities will be presented elsewhere.

Acknowledgements. The authors wish to thank Messrs O. Kuroda, Y. Kito and Y. Ohta for their excellent technical assistance. One (T.K.) of the authors contributed through the present report (Contribution No. 24-1973) to his own institution.

\section{REFERENCES}

1) T. Kada, Ann. Rep. Nat. Inst. Genet. (Japan), 24, 43 (1974).

2) D. J. Morgan, J. Appl. Chem, 9, 201 (1959).

3) V. Meyer and E. J. Constam, Ann., 214, 329 (1882).

4) T. Kada, K. Tsuchikawa and Y. Sadaie, Mutation Res., 16, 165 (1972). 